\title{
Non-genetic inheritance: Evolution above the organismal level
}

\author{
Anton V. Sukhoverkhov ${ }^{a, *}$, Nathalie Gontier ${ }^{\mathrm{b}}$ \\ ${ }^{a}$ Department of Philosophy, Kuban State Agrarian University, Kalinina St. 13, 350044, Krasnodar, Russia \\ ${ }^{\mathrm{b}}$ Applied Evolutionary Epistemology Lab, Centro de Filosofia das Ciências, Departamento de História e Fïlosofia das Ciências, Faculdade de Ciências, Universidade de \\ Lisboa, 1749-016, Lisboa, Portugal
}

\section{A R T I C L E I N F O}

\section{Keywords:}

Non-genetic inheritance

Social plasticity

Community traits

Reticulate evolution

Extended evolutionary synthesis

\begin{abstract}
A B S T R A C T
The article proposes to further develop the ideas of the Extended Evolutionary Synthesis by including into evolutionary research an analysis of phenomena that occur above the organismal level. We demonstrate that the current Extended Synthesis is focused more on individual traits (genetically or non-genetically inherited) and less on community system traits (synergetic/organizational traits) that characterize transgenerational biological, ecological, social, and cultural systems. In this regard, we will consider various communities that are made up of interacting populations, and for which the individual members can belong to the same or to different species. Examples of communities include biofilms, ant colonies, symbiotic associations resulting in holobiont formation, and human societies. The proposed model of evolution at the level of communities revises classic theorizing on the major transitions in evolution by analyzing the interplay between community/social traits and individual traits, and how this brings forth ideas of top-down regulations of bottom-up evolutionary processes (collaboration of downward and upward causation). The work demonstrates that such interplay also includes reticulate interactions and reticulate causation. In this regard, we exemplify how community systems provide various nongenetic 'scaffoldings', 'constraints', and 'affordances' for individual and sociocultural evolutionary development. Such research complements prevailing models that focus on the vertical transmission of heritable information, from parent to offspring, with research that instead focusses on horizontal, oblique and even reverse information transmission, going from offspring to parent. We call this reversed information transfer the 'offspring effect' to contrast it from the 'parental effect'. We argue that the proposed approach to inheritance is effective for modelling cumulative and distributed developmental process and for explaining the biological origins and evolution of language.
\end{abstract}

\section{Introduction}

Following Darwin, the founders of the Modern Synthesis defined evolutionary research as the study of how individual, genetic traits are inherited and transmitted through time. Proponents of the Extended Evolutionary Synthesis (Pigliucci, 2009; Danchin et al., 2011; Pigliucci and Müller, 2010) have in addition recognized the growing empirical and theoretical evidence for the existence of epigenetic and non-genetic inheritance systems (Laland et al., 2015; Stotz, Griffiths, 2016). On a meso-scale, Jablonka and Lamb (2005) for example distinguished between four kinds of inheritance systems: genetic, epigenetic, behavioral, and symbolic. Studies of phenotype-environmental interactions have led to the idea of niche construction (Lewontin, 1982; Laland et al., 2015; Stotz, 2017). And Odling Smee (2007) has complemented the notion of niche construction with ecological inheritance theory.
However, most extended models focus on physiological and developmental aspects of organismal evolution on the one hand, and on the other, on the relation between non-genetic mechanisms and phenotype-environmental interactions (Danchin, Pocheville, 2014; Lu, Bourrat, 2018). The Extended Evolutionary Synthesis thus remains focused on studying individual organisms and the inheritance, transmission, and development of organismal traits. Here we investigate how extended views on evolution can be further extended toward phenomena that occur above the organismal level.

By recognizing that evolution also occurs above the organismal level, we expand on the well-developed and today also well-recognized theories about kin selection (Hamilton, 1964a, 1964b; Queller, 1992), reciprocal altruism (Trivers, 1971, 1985), group selection (Alexander and Borgia, 1978; Wilson, 1980; Wilson and Sober, 1994), species selection and species sorting (Gould and Eldredge, 1988; Jablonski, 2008; Lloyd

\footnotetext{
* Corresponding author.

E-mail addresses: sukhoverkhov.ksau@gmail.com (A.V. Sukhoverkhov),nlgontier@ciencias.ulisboa.pt (N. Gontier).
} 
and Gould, 1993; Stanley, 1975; Vrba and Gould, 1986). These theories have often focused on the evolution of kin, groups, populations, or species. In our research we will be focusing on communities and their newly emerging system properties (social, synergetic, organizational traits). We define communities as agglomerations of interacting populations of which the individual members can belong to the same as well as to different species (Table 1). Our definition of communities also extends toward the environments inhabited and the niches constructed by these communities.

Examples of such communities in biology include ant colonies (Wilson and Sober, 1989), microbial systems (Woolfson, 2016), or symbiotic associations (Carrapiço, 2015) that function as superorganisms or that lead to holobiont formation (Margulis et al., 1991; Gontier, 2015). In cognitive and sociocultural studies, examples include the various niches that are constructed at or above the level of the organism such as 'eco-cultural niches' (Banks et al., 2006), linguistic niches (Dale and Lupyan, 2012) or human society in general (Kesebir, 2012; Mashnogorskaya, Sukhoverkhov, 2017).

We will refer to system properties (social, synergetic, organizational traits) as community traits and we define them as the cumulative, transgenerational, and constructed properties resulting from both genetic and non-genetic (i.e. biological, ecological, and sociocultural) inheritance. Community traits are dynamic, synergetic and distributed traits that characterize the community as a whole rather than their individual members separately. Examples include technologies, languages, cultures, or behavior portrayed by the group. Biofilms such as dental plaque, for example, demonstrate more resistance to environmental perturbations than do the individual bacterial groups that make up the biofilms. Cumulative tool manufacture and use, the origin of symbols-notation systems, or the emergence and community-wide spread of cognitive and behavioral traits (like literacy, hygiene, agriculture, etc.) also can be considered as organism-transcending, intersubjective community traits that evolve in space and over time, just like genetic and individual behavioral traits do.

Communities can be understood as specific levels of evolution and community traits as units of evolution, including evolution as it occurs by means of natural selection (Table 1). Communities and their traits have heterogenous structures (that consist of multiple sublevels and subunits) and they exemplify the existence of organizational mechanisms and synergistic properties that are different from the properties of individuals (Corning, 2010; Carrapiço, 2015; Danchin et al., 2015; Corning, 2018).

By switching the focus from genes (typical of the Modern Synthesis) and organisms (typical of the Extended Synthesis) to communities and the traits they portray, we can integrate macro-oriented biological,

Table 1

Proposed new units and levels of evolution.

\begin{tabular}{|c|c|c|}
\hline $\begin{array}{l}\text { Elements of } \\
\text { Evolution }\end{array}$ & Definition & Examples \\
\hline $\begin{array}{l}\text { Communities as } \\
\text { levels of } \\
\text { evolution }\end{array}$ & $\begin{array}{l}\text { An agglomeration of } \\
\text { interacting populations of } \\
\text { which the individual members } \\
\text { can belong to the same as well } \\
\text { as to different species. } \\
\text { Communities include the biotic } \\
\text { and abiotic environmental } \\
\text { niche inhabited and } \\
\text { constructed by the community. }\end{array}$ & $\begin{array}{l}\text { Biofilms, ant colonies, } \\
\text { groups, holobionts, niches, } \\
\text { societies }\end{array}$ \\
\hline $\begin{array}{l}\text { Community traits } \\
\text { as units of } \\
\text { evolution }\end{array}$ & $\begin{array}{l}\text { Synergistic/organizational } \\
\text { traits that characterize the } \\
\text { community and that result } \\
\text { from the cumulative, } \\
\text { transgenerational, and } \\
\text { constructed niches resulting in } \\
\text { turn from biological, } \\
\text { ecological, and sociocultural, } \\
\text { extra-genetic inheritance. }\end{array}$ & $\begin{array}{l}\text { Group behavior, societal } \\
\text { traits, languages, cultures, } \\
\text { artifacts and technological } \\
\text { complexes }\end{array}$ \\
\hline
\end{tabular}

ecological, and sociocultural evolution studies into the newly evolving evolutionary paradigm. Consequently, we need to commence a study of how transgenerational and intersubjective behavioral, cognitive, ecological, and sociocultural 'community traits' impact both the micro- (genetic, physiological, developmental) and macro-levels of evolution.

Thus, the article is aimed to outline the possible theoretical integrations of genetic and non-genetic inheritance theories that could embrace both the individual and system 'transitions' in evolution. It will be shown that systematized and advanced theories of 'extended inheritance' can function as a uniform scientific language for understanding evolution on the organismal and above the organismal level. We revise current obstacles in 1) studies of non-genetic inheritance and 2) recognition of community-level aspects of evolution. Finally, we exemplify our approach by looking at the case of human language as a community trait and the role that non-genetic inheritance plays in its transmission and development.

\section{Evolution beyond individual physiology}

We think that studies of non-genetic inheritance are currently hindered by two main obstacles that are caused by prevailing ideas in mainstream theories of evolution.

- The first obstacle is the persistent ascription of a whole suite of phenotypic characters (physiological, behavioral, cognitive, social) to genetic or 'innate' causes (Stotz, 2010).

- The second is the 'traditional' reductionist understanding of inheritance in terms of the vertical transmission, from parent to offspring, of genetically underlain traits (Uller, Helanterá, 2013; Danchin and Pocheville, 2014; Uller and Helanterä, 2019; Laland et al., 2015).

Regarding the first obstacle, received wisdom states that traits need to be genetically underpinned. However, many traits portrayed by groups, such as collective hunting, compositional tool manufacture, the rise of agriculture, etc., cannot be reduced to individual genetic traits and explained by 'hard inheritance' (Jablonka, Lamb, 2008). Rather, the emergence of these features is scaffolded by extra-genetic, biological, ecological, and sociocultural affordances that are accumulated in shared material culture (niches) and shared actions (Igamberdiev, 1992, 2017; IJzerman et al., 2015; Mashnogorskaya and Sukhoverkhov, 2017; McElreath, 2010). These features are transmitted to subsequent generations not by genes alone (Richerson and Boyd, 2005) but through sociocultural learning (behavioral, symbolic, cultural inheritance). Taking the evolution of wheat and the farming of wheat by humans as an example, McElreath et al. (2010) notes that:

"Much of the knowledge that most farmers employ to manage wheat accumulated over many generations, but it isn't contained in anyone's genome ... no individual in the course of his or her lifetime could accumulate it. Instead, it has taken many generations to develop, in a way similar to how information over many generations accumulated in wheat's genome" (p. 453).

This and other examples show that such 'soft' or non-genetic inheritance has functional and structural isomorphisms with genetic ('hard') inheritance; both are transgenerational, cumulative and both maintain (trans)generational informational 'discourse' (Mashnogorskaya, Sukhoverkhov, 2017; Pharoah, 2018; Markoš, Faltýnek, 2011). Nonetheless, they also differ from one another because vertical transmission of information in such complex, transgenerational communities is complemented by horizontal and other types of information transmission. This fact enables us to overcome the second obstacle.

Scientists in social studies agreed that there are three directions in 'cultural traits' transmission: vertical (from parents to offspring), horizontal (from peer to peer) and oblique (from teacher/mentor to student) (Boyd, Richerson, 1982). However, we think that these types of transmission can be applied to biological systems too. Horizontal transmission, for instance, typifies processes of lateral gene transfer in and 
between microorganisms, and oblique transmission typifies ecological and behavioral inheritance in social animals (Cavalli Sforza, 1981; Griffiths et al., 2001, p. 202; Jablonka and Lamb, 2005; Gontier, 2012; Merhej and Raoult, 2012). In cases of cultural inheritance, even the reverse direction of trait transmission can be found. A good example of this is computer literacy where "culture does not follow linear means of transmission that is typical of evolution by means of natural selection. Rather, grandchildren can teach their grandparents how to use the computer ...' (Gontier, 2012, p. 103). In this case younger generations give social affordances (or scaffolds) for the usage of modern devices and technologies to older generations (e.g. to their grandparents) and they can in turn teach the acquired skills to members of their or other generations. We call this reverse inheritance the 'offspring effect' in contrast with the 'parental effect'.

Such 'effect' can be seen in all forms of technological or sociocultural evolution and the phenomenon requires an understanding of reticulate causation that extends traditional genealogical hierarchies where genes are theorized to bring forth organisms and species. As such, information can 'flow' in all directions, from organisms to genes, from parents to offspring, from organisms belonging to one species to organisms belonging to another.

\section{The role of top-down and reticulate causation in evolution}

Social traits can emerge at a community level, and they can be transmitted over generations through time as well as undergo further evolutionary developments. Recognizing this calls out for a revision of both the Modern and the Extended Evolutionary Synthesis. The former school understands evolution in terms of upward causation that brings forth affordances, while the latter school in addition recognizes downward causation that imposes constraints on evolving systems (Campbell et al., 1974). Much of current evolutionary research is therefore cast in terms of how 'external' ecological, social, semiotic and other factors influence individual and social development by providing various 'scaffoldings', 'constraints', and 'affordances' (John-Steiner, Mahn, 1996; Boyd et al., 2011; Robinson et al., 2008; Sukhoverkhov, 2015; Kull, 2015).

Additionally, we draw attention to the existence of reticulate causal processes (Gontier et al., 2018,) that occur within communities and that underlie bioreality formation (Table 2). During holobiont formation, for example, different organisms cooperate synergistically to form a community that simultaneously functions as a new habitable zone of life. Research on reticulate evolution (Gontier, 2015, 2018) demonstrates how the evolution of holobionts requires us to understand evolutionary hierarchies as multiple and interacting. Such accounts presuppose a shift of focus from mechanical explanations to process accounts (Sukhoverkhov, 2015; Stotz, Griffiths et al., 2017; Gontier et al., 2018).

\section{From individual phenotypic plasticity to 'social plasticity'}

By recognizing non-genetic inheritance and community processes of evolution, we propose to complement terms such as 'individual phenotypic plasticity' (also known as 'developmental plasticity') with 'social plasticity'. Individual developmental plasticity enables the fast acquisition and transmission of newly achieved adaptations, thereby bypassing a long process of genetic mutations. Social plasticity helps to overcome biological limits of single organisms through welldocumented processes such as niche construction (Lewontin, 1982), labor division (Ridley, 2010; West and Cooper, 2016) extended cognition (Clark and Chalmers, 1998) as it becomes materialized into cultural artifacts or socially distributed actions. Even bacteria are able to work as a team and they can share and incorporate into their genetic code fragments of DNA from the (social) environment (Overballe-Petersen et al., 2013; Shapiro, 2011; West and Cooper, 2016). Implementing these ideas into theorizing on the major transitions in evolution could further improve our understanding of how social animals transmit
Table 2

Reticulate causation within and between different species brings forth communities that underlie bioreality formation (after Gontier 2020).

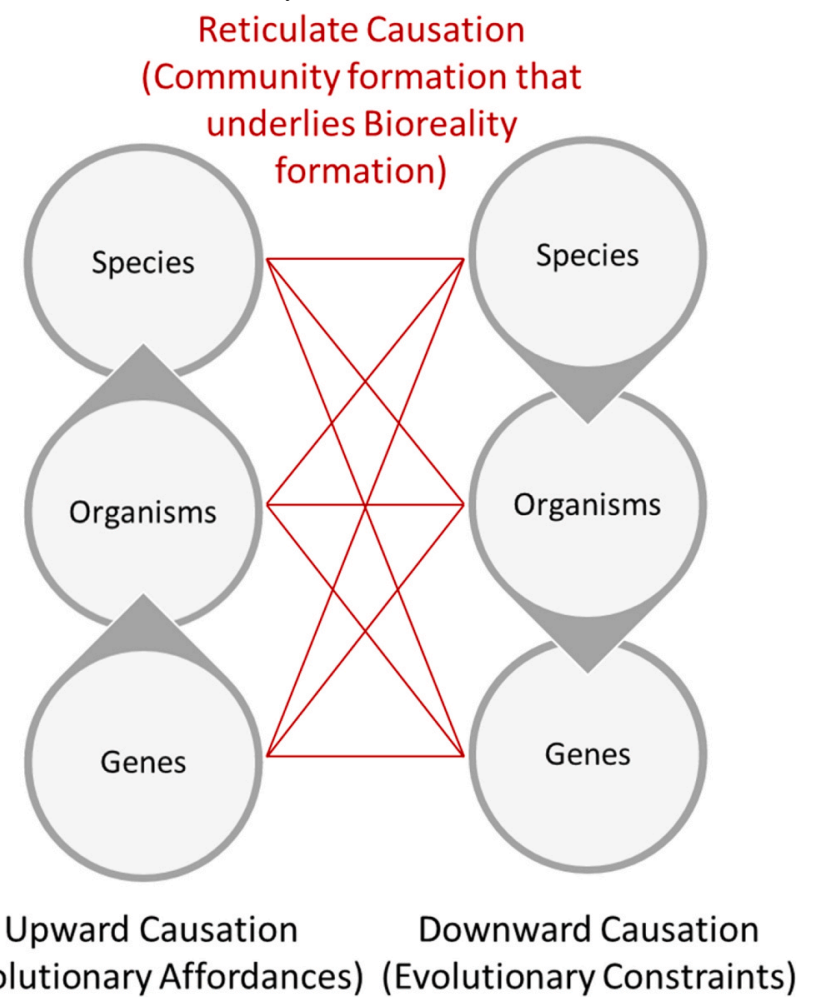

non-genetic information across societies (Stotz and Griffiths, 2016; Danchin, Pocheville, 2014; Stotz, 2014).

It is important to emphasize that both individual plasticity and creativity play a crucial role in the origin, maintenance and development of transgenerational and community processes in evolution. Individual plasticity enables fast transgenerational cultural evolution through extragenetic inheritance. For instance, transgenerational and cumulative social processes like agriculture emerge and are maintained via the individual acquisition and practical transmission of cultural achievements (technical skills, language, scientific knowledge, etc.). However, individual creativity allows not just the faithful acquisition and storage of information from the past but also the active introduction of newly invented actions or traits that can be utilized as new items to be used and passed on to future generations. And this is what makes individuals alter existing niches (Wiggins et al., 2015; Fogarty et al., 2015).

Female dolphins of Shark Bay, for example, only recently started using sponges as a foraging tool, they did not acquire it from their parents but are now transmitting the trait to their offspring (Krutzen et al., 2005); among apes it is common to have dozens of local traditions (Whiten et al., 2007); and bees, birds and whales make and adopt new communicative 'dialects' from their or even other species (McGregor et al., 1988; Su et al., 2008; Garland et al., 2011). In human society, younger generations can inherit, produce and share a variety of new behavioral, cultural, and cognitive traits. For instance, they can 'repost' new semiotic means and skills of communication (technical, artistic, professional), they can use new clothes, makeup, hairstyles, ways of movement and greeting that change their physiological and cultural appearance and that distinguish them from previous generations. All these 'traits' are distributed on a community level, transmitted and maintained by non-genetic inheritance (sometimes in the form of dynamic 'cultural ripples') and acquired by imitation or socially-mediated learning.

These active contributions of individuals bring forth the problem of 
the interplay between social and individual phenotypes/plasticities. Following other scholars (Clark and Chalmers, 1998; Donald et al., 2000; Leadbeater, Chittka, 2007; Sutton et al., 2004; Sutton, 2008; van Schaik, Burkart, 2011), we agree that there is a cyclic causality between organisms (their traits) and the community that they constitute. In some regards, ecological niches, cultures and societies function as distributed 'memory systems' that accumulate, mediate, and direct the development of their individuals. In turn, individuals contribute to this 'memory' through actively inhabiting, constructing, and reconstructing the niches (Laland et al., 2008; Sutton, 2008; Sukhoverkhov, 2010).

It is important to emphasize that during the course of evolution, the inheritance of community traits occurred not merely by being born into a specific environment, but through learning (which to some extend can be passive) and teaching (which is always active) (Thornton, Raihani, 2010; Laland, 2017). In human society, we even have specialized social institutes responsible for knowledge and skills transmission (e.g. Ministries of Education and Science, universities, or schools). These institutes exemplify social 'developmental niches' and an active, top-down (as opposed to bottom-up) regulation of individual development.

These non-genetically inherited traits transcend individuals and, quite often, the generations they belong to. For example, natural language, computer technologies, or ecological consciousness could be interpreted as 'traits' of social communities that exist and that will persist through time and space relatively independent of the particular individuals that created and used them. These traits (cognitive skills, system of actions, tools, etc.) are also in constant (re)development because they form integral parts of individual activities whereby they extend into the niche. This again creates a form of reciprocal causality (Pharoah, 2018; Svensson, 2018; Buskell, 2019), not only between organisms and their constructed environment, but also within the social community and their constituents, between community traits and individual traits.

Literacy, for instance, is taken for granted nowadays. However, its major role in knowledge transition and social development was promoted during the Age of Enlightenment, when it became an integral component of the social community wherein top-down social/governmental regulation of literacy development occurred. In the 1920s and 1930s, the Soviet Union launched the 'Likbez' program where over 50 million adults were trained in reading and writing skills (especially in rural areas). After 20 years, almost $90 \%$ of the people became literate ${ }^{1}$ (Alexander and Borgia, 1978). Later it preconditioned (bootstrapped) the scientific and technological boom in Soviet Russia. In this regard, the 'tradition' of literacy in society bootstraps development of science and technology, and in turn, this development forms new demands for peoples' education, thereby necessitating new 'social traits' (e.g. computer literacy, advanced math literacy, etc.).

Social plasticity correlates with the ability of society to codify, accumulate, maintain and transmit useful knowledge for collective niche construction. And here, cumulative cultural evolution and advancement of labor division (distributed actions) have played a key role for human evolution (McElreath et al., 2010; Sterelny, 2016). It allowed human populations to settle in all corners of the world and to distribute, on a societal level, knowledge, skills and actions to such a degree that it enabled the division of labor and the rise of specialized skills (Ridley, 2010 pp. 2-5).

Beyond human cultures, there are many examples of cultural inheritance, cumulative culture, and division of labor in nature (Danchin et al., 2010; Dean et al., 2014; West, Cooper, 2016; Laland, Evans, 2017). In all cases, social plasticity is constrained by individual plasticity but because of the distribution of cognition and action in society, individual constrains can be overcome, leading to social trans-individualism and trans-generationalism and the emergence of synergistic, community-level traits that come to define constructed niches (Corning,

$\overline{1}$ https://www.rbth.com/history/330903-bolsheviks-taught-russians-to-read.
2008).

\section{Language beyond DNA: the problem of language origin and evolution}

Language evolution studies can also benefit from non-genetic inheritance and community system approaches to evolution. So far, attempts to explain the biological origins and nature of language have focused on an analysis of individual and innate linguistic competences (Hauser et al., 2002; Pinker, Bloom, 1990). However, the proponents of this approach recently recognized that such a project has failed (Hauser et al., 2014). In our view, this failure was due to the fact that languages were not addressed as intersubjective, transgenerational systems of communication that are embodied in multiple organisms and embedded into social communities or ecosystems (Steffensen, Fill, 2014). Languages are cumulative, sociocultural, and symbolic, and as such, languages presuppose not only fixed innate modules but also broad individual plasticity, cultural inheritance, and socially mediated learning and teaching at a community level (Sukhoverkhov, Fowler, 2014; Laland, 2017; Steels, Szathmáry, 2018).

Nobody knows his/her native language completely ${ }^{2}$ (Axelrod and Hamilton, 1981). Rather it exists beyond the skillset of a particular speaker and it is 'never complete in any single individual' (Saussure, 1983 p. 13). In this regard, languages are patchy and heterogenous community traits. Their 'complete' existence is distributed among different people and 'cannot be located in a single place, or on a single time-scale' (Linell, 2013 p. 169). As a transgenerational and non-local community trait it is also hybrid and symbiotic because its existence embodies, embeds, and resides in various individual, social and natural 'realities' where it has different idiolects, dialects, borrowings, etc. (Burridge, 2004; Sukhoverkhov, Fowler, 2014; Linell, 2013).

Languages are non-genetic heritable traits brought forth by the community, and as such they can be changed and molded by their individual learners, thereby bringing forth a dialectic causality between groups and individuals. By accumulating knowledge and regulating actions, languages, as well as other conventional semiotic systems (e.g. mathematic and music notation, road signs, money, etc.), function as scaffolds for individual development enabling higher cognitive functions like reasoning or counting (Vygotsky, 1981). Also, languages are the resource that is scaffolded and maintained by individuals through learning and teaching (Laland, 2017). Therefore, an integral theory of language evolution should embrace micro- and macro-evolutionary approaches and upward and downward models of causation, as well as reticulate causation. Because language and other sign systems play a crucial role in the accumulation, transmission and reproduction of culture and society, we can also understand it as a medium for social memory (Sutton et al., 2004, 2008; Sukhoverkhov, 2010), where cultural (social) evolution occurs.

The communicative (semiotic) plasticity of a brain and the cultural inheritance and transmission of semiotic toolkits and skillsets of communication are not intrinsically a human feature. Socially transmitted 'dialects' are also found in bees, whales and birds (Marler, Tamura, 1964; Su et al., 2008; Garland et al., 2011). Advanced neural plasticity, similar to humans' 'critical period', have been discovered in zebra finches (Bolhuis et al., 2010; White, 2001). Even rudimentary forms of recursion (described by many scholars as uniquely human ability) have been found in birds (Hailman et al., 1985; Berwick et al., 2011). And research also points toward the acquisition of other conventional semiotic systems like mathematic notations or money usage (Pepperberg, 2006; De Petrillo et al., 2019). Animal abilities thus

\footnotetext{
${ }^{2}$ For example, according to the Global Language Monitor English language has $1,057,379.6$ words (on 1 January 2020) and about 14.7 words are being created per day. http://www.languagemonitor.com/global-english/no-of-wo rds.
} 
include the learning of novel, non-genetically-wired communication.

All this lets us propose that the evolution of communication and language and the usage of other semiotic and cognitive tools emerged not only in the course of human evolution (Everett, 2017), their prerequisites can already be found in animals (Hoffmeyer, 2007; Kull, 2015; Pharoah, 2018, 2020). Such development became possible because of three main factors: 1) developmental plasticity, 2) non-genetic (behavioral, social, cultural) inheritance, and 3) socially mediated learning/teaching that is found both in biological and social systems.

\section{Conclusion}

The Extended Synthesis was introduced within evolutionary developmental schools of thought with the goal to implement a more organismal-focused outlook in evolutionary theory, one that surpasses the gene-centered outlook of the Neo-Darwinian synthesis. However, the Extended Synthesis can also be extended toward phenomena that transcend the organism. And here too, non-genetic inheritance plays a crucial role in our understanding of above-organismal, social, cultural, and ecological phenomena. The reticulate transmission of non-genetic information contained in material culture and social traits can be understood as emerging from synergistic interactions between multiple gene-bearing individuals, but it cannot be reduced to these forms of 'hard inheritance'. This becomes evident when we take into account that such sociocultural systems gain independence from the particular individuals that first introduced them, thereby enabling cumulative sociocultural evolution that spans across generations. In this regard we think that the extended and distributed models of cognition could be useful to understand the general evolution of inheritance, and that this could be extended toward the level of communities and their community traits. Finally, 'community plasticity' and 'social plasticity' should be taken into account in the bottom-up, top-down and reticulate models of evolution.

\section{Acknowledgements}

Gontier acknowledges the financial support of FCT, the Portuguese Foundation for Science and Technology, Grant ID DL57/2016/CP1479/ CT0066 and Project IDs: UID/FIL/00678/2019 \& UIDB/00678/2020.

\section{References}

Alexander, R.D., Borgia, G., 1978. Group selection, altruism and the levels of organization of life. Annu. Rev. Ecol. Systemat. 9, 449-475.

Axelrod, R., Hamilton, W.D., 1981. The evolution of cooperation. Science 211 , 1390-1396.

Banks, W.E., d'Errico, F., Dibble, H.L., Krishtalka, L., West, D., Olszewski, D.I.,, et al., 2006. Eco-cultural niche modeling: new tools for reconstructing the geography and ecology of past human populations. PaleoAnthropology 4 (6), 68-83.

Berwick, R.C., Okanoya, K., Beckers, G.J., Bolhuis, J.J., 2011. Songs to syntax: the linguistics of birdsong. Trends Cognit. Sci. 15 (3), 113-121.

Bolhuis, J.J., Okanoya, K., Scharff, C., 2010. Twitter evolution: converging mechanisms in birdsong and human speech. Nat. Rev. Neurosci. 11 (11), 747-759.

Boyd, R., Richerson, P.J., 1982. Cultural transmission and the evolution of cooperative behavior. Hum. Ecol. 10 (3), 325-351.

Boyd, R., Richerson, P.J., Henrich, J., 2011. The cultural niche: why social learning is essential for human adaptation. Proc. Natl. Acad. Sci. Unit. States Am. 108 (Suppl. 2), 10918-10925.

Burridge, K., 2004. Blooming English: Observations on the Roots, Cultivation and Hybrids of the English Language. Cambridge University Press.

Buskell, A., 2019. Reciprocal causation and the extended evolutionary synthesis. Biological Theory 14 (4), 267-279.

Campbell, D.T., 1974. Downward causation in hierarchically organized biological systems. In: Ayala, F.J., Dobzhansky, T. (Eds.), Studies in the Philosophy of Biology. Macmillan, London, pp. 179-186.

Carrapiç, F., 2015. Can we understand evolution without symbiogenesis? In: Gontier, N. (Ed.), Reticulate Evolution. Springer, Cham, pp. 81-105.

Cavalli-Sforza, L.L., Feldman, M.W., 1981. Cultural Transmission and Evolution: A Quantitative Approach (No. 16). Princeton University Press.

Clark, A., Chalmers, D., 1998. The extended mind. Analysis 58 (1), 7-19.

Corning, P., 2010. Holistic Darwinism: Synergy, Cybernetics, and the Bioeconomics of Evolution. University of Chicago Press.
Corning, P.A., 2008. Holistic Darwinism: the new evolutionary paradigm and some implications for political science. Polit. Life Sci. 27 (1), 22-54.

Corning, P.A., 2018. Synergistic Selection: How Cooperation Has Shaped Evolution and the Rise of Humankind, vol. 3. World Scientific, Singapore, London, Hackensack.

Dale, R., Lupyan, G., 2012. Understanding the origins of morphological diversity: the linguistic niche hypothesis. Adv. Complex Syst. 15, 1150017, 03n04.

Danchin, E., Pocheville, A., 2014. Inheritance is where physiology meets evolution. J. Physiol. 592 (11), 2307-2317.

Danchin, É.G., Blanchet, S., Mery, F., Wagner, R.H., 2010. Do invertebrates have culture? Commun. Integr. Biol. 3 (4), 303-305.

Danchin, E., B Corning, P.A., Szathmáry, E., 2015. "Synergistic selection": a Darwinian frame for the evolution of complexity. J. Theor. Biol. 371, 45-58.

Danchin, E., Charmantier, A., Champagne, F.A., Mesoudi, A., Pujol, B., Blanchet, S., 2011. Beyond DNA: integrating inclusive inheritance into an extended theory of evolution. Nat. Rev. Genet. 12 (7), 475-486.

De Petrillo, F., Caroli, M., Gori, E., Micucci, A., Gastaldi, S., Bourgeois-Gironde, S., Addessi, E., 2019. Evolutionary origins of money categorization and exchange: an experimental investigation in tufted capuchin monkeys (Sapajus spp.). Anim. Cognit. 22 (2), 169-186.

Dean, L.G., Vale, G.L., Laland, K.N., Flynn, E., Kendal, R.L., 2014. Human cumulative culture: a comparative perspective. Biol. Rev. 89 (2), 284-301.

Donald, M., 2000. The central role of culture in cognitive evolution: a reflection on the myth of the "Isolated mind". In: Nucci, L., Saxe, G.B., Turie, E. (Eds.), Culture, Thought and Development. Lawrence Erlbaum Associates, Mahwah, New Jersey, pp. 19-38.

Everett, D.L., 2017. Grammar came later: triality of patterning and the gradual evolution of language. J. Neurolinguistics 43, 133-165.

Fogarty, L., Creanza, N., Feldman, M.W., 2015. Cultural evolutionary perspectives on creativity and human innovation. Trends Ecol. Evol. 30 (12), 736-754.

Garland, E.C., Goldizen, A.W., Rekdahl, M.L., et al., 2011. Dynamic horizontal cultural transmission of humpback whale song at the ocean basin scale. Curr. Biol 21 (8), 687-691.

Gontier, N., 2012. Introducing universal symbiogenesis. In: Pombo, O., et al. (Eds.), Special Sciences and the Unity of Science. Springer, Dordrecht, pp. 89-111.

Gontier, N., 2015. Reticulate evolution everywhere. In: Gontier, N. (Ed.), Reticulate Evolution: Symbiogenesis, Lateral Gene Transfer, Hybridization and Infectious Heredity. Springer, Cham, pp. 1-40.

Gontier, N., 2018. On how epistemology and ontology converge through evolution: the applied evolutionary epistemological approach. In: Wuppuluri, S., Doria, F. (Eds.), The Map and the Territory. Springer, Cham, pp. 533-569.

Gontier, N., 2020. Hierarchies, networks, and causality: the applied evolutionary epistemological approach. J. Gen. Philos. Sci.

Griffiths, P.E., Stotz, K., 2017. Developmental systems theory as a process theory. In: Nicholson, D.J., Dupre, J. (Eds.), Everything Flows: Towards a Processual Philosophy of Biology. Oxford University Press, Oxford, NY, pp. 225-246.

Gould, S., Eldredge, N., 1988. Species selection: its range and power. Nature 334, 19.

Griffiths, P.E., Gray, R.D., 2001. Darwinism and developmental systems. In: Oyama, S., Griffth, P.E., Gray, R.D. (Eds.), Cycles of Contingency: Developmental Systems and Evolution. MIT Press, Cambridge, Mass, pp. 195-219.

Hailman, J.P., Ficken, M.S., Ficken, R.W., 1985. The 'chick-a-dee'calls of Parus atricapillus: a recombinant system of animal communication compared with written English. Semiotica 56 (3-4), 191-224.

Hamilton, W.D., 1964a. The genetical evolution of social behaviour, II. J. Theor. Biol. 7, $1-16$.

Hamilton, W.D., 1964b. The genetical evolution of social behaviour. II. J. Theor. Biol. 7 (1), 17-52.

Hauser, M.D., Chomsky, N., Fitch, W.T., 2002. The faculty of language: what is it, who has it, and how did it evolve? Science 298 (5598), 1569-1579.

Hauser, M.D., Yang, C., Berwick, R.C., Tattersall, I., Ryan, M.J., Watumull, J.,, et al., 2014. The mystery of language evolution. Front. Psychol. 5, 401.

Hoffmeyer, J., 2007. Semiotic scaffolding of living systems. In: Barbieri, M. (Ed.), Introduction to Biosemiotics: the New Biological Synthesis. Springer, Dordrecht, pp. 149-166.

Igamberdiev, A.U., 1992. Organization of biosystems: a semiotic approach. In: Sebeok, T. A., Umiker-Sebeok, J. (Eds.), The Semiotic Web 1991: Biosemiotics, vol. 106. De Gruyter Mouton, pp. 125-144.

Igamberdiev, A.U., 2017. Evolutionary transition from biological to social systems via generation of reflexive models of externality. Prog. Biophys. Mol. Biol. 131, $336-347$.

IJzerman, H., Coan, J.A., Wagemans, F.M., Missler, M.A., van Beest, I., Lindenberg, S. Tops, M., 2015. A theory of social thermoregulation in human primates. Front. Psychol. 6, 464.

Jablonka, E., Lamb, M.J., 2005. Evolution in Four Dimensions: Genetic, Epigenetic, Behavioral, and Symbolic Variation in the History of Life. MIT Press.

Jablonka, E., Lamb, M.J., 2008. Soft inheritance: challenging the modern synthesis. Genet. Mol. Biol. 31 (2), 389-395.

Jablonski, D., 2008. Species selection: theory and data. Annu. Rev. Ecol. Evol. Syst. 39, 501-524.

John-Steiner, V., Mahn, H., 1996. Sociocultural approaches to learning and development: a Vygotskian framework. Educ. Psychol. 31 (3-4), 191-206.

Kesebir, S., 2012. The superorganism account of human sociality: how and when human groups are like beehives. Pers. Soc. Psychol. Rev. 16 (3), 233-261.

Krutzen, M., Mann, J., Heithaus, M.R., Conner, R.C., Bejder, L., Sherwin, W.B., 2005. Cultural transmission of tool use in bottlenose dolphins. Proc. Natl. Acad. Sci. Unit. States Am. 102 (25), 8938-8943. 
Kull, K., 2015. Evolution, choice, and scaffolding: semiosis is changing its own building. Biosemiotics 8 (2), 223-234.

Laland, K.N., 2017. The origins of language in teaching. Psychon. Bull. Rev. 24 (1), 225-231.

Laland, K., Evans, C., 2017. Animal Social Learning, Culture, and Tradition. APA Handbook of Comparative Psychology: Perception, Learning, and Cognition, vol. 2. American Psychological Association, Washington, DC, US, pp. 441-460 xiii, 841.

Laland, K.N., Odling-Smee, J., Gilbert, S.F., 2008. EvoDevo and niche construction: building bridges. J. Exp. Zool. B Mol. Dev. Evol. 310 (7), 549-566.

Laland, K.N., Uller, T., Feldman, M.W., Sterelny, K., Müller, G.B., Moczek, A.,, et al., 2015. The extended evolutionary synthesis: its structure, assumptions and predictions. Proc. Biol. Sci. 282 (1813), 20151019.

Leadbeater, E., Chittka, L., 2007. Social learning in insects-from miniature brains to consensus building. Curr. Biol. 17 (16), R703-R713.

Lewontin, R., 1982. Organism and environment. In: Plotkin, H. (Ed.), Learning, Development and Culture: Essays in Evolutionary Epistemology. Wiley, New York, NY, pp. 151-170.

Linell, P., 2013. Distributed language theory, with or without dialogue. Lang. Sci. 40, $168-173$.

Lloyd, E.A., Gould, S.J., 1993. Species selection on variability. Proc. Natl. Acad. Sci. Unit. States Am. 90, 595-599.

Lu, Q., Bourrat, P., 2018. The evolutionary gene and the extended evolutionary synthesis. Br. J. Philos. Sci. 69 (3), 775-800.

Margulis, L., 1991. Symbiogenesis and symbionticism. In: Margulis, L., Fester, R. (Eds.), Symbiosis as a Source of Evolutionary Innovation. MIT Press, Cambridge, MA, pp. 1-14.

Markoš, A., Faltýnek, D., 2011. Language metaphors of life. Biosemiotics 4 (2), 171-200.

Marler, P., Tamura, M., 1964. Culturally transmitted patterns of vocal behavior in sparrows. Science 146 (3650), 1483-1486.

Mashnogorskaya, A.A., Sukhoverkhov, A.V., 2017. Isomorphism of system stages of evolution, 126. Polythematic Online Scientific Journal of Kuban State Agrarian University, pp. 1-17, 2.

McElreath, R., 2010. The coevolution of genes, innovation and culture in human evolution. In: Kappeler, P.M., Silk, J.B. (Eds.), Mind the Gap: Tracing the Origins of Human Universals. Springer-Verlag, Berlin, Heidelberg, pp. 451-474.

McGregor, P.K., Walford, V.R., Harper, D.G., 1988. Song inheritance and mating in a songbird with local dialects. Bioacoustics 1 (2-3), 107-129.

Merhej, V., Raoult, D., 2012. Rhizome of life, catastrophes, sequence exchanges, gene creations, and giant viruses: how microbial genomics challenges Darwin. Frontiers in cellular and infection microbiology 2 (113), 1-17.

Odling-Smee, F.J., 2007. Niche inheritance: a possible basis for classifying multiple inheritance systems in evolution. Biological Theory 2 (3), 276-289.

Overballe-Petersen, S., Harms, K., Orlando, L.A., et al., 2013. Bacterial natural transformation by highly fragmented and damaged DNA. Proc. Natl. Acad. Sci. Unit. States Am 110 (49), 19860.

Pepperberg, I.M., 2006. Grey parrot numerical competence: a review. Anim. Cognit. 9 (4), 377-391.

Pharoah, M., 2018. Qualitative attribution, phenomenal experience and being. Biosemiotics 11 (3), 427-446.

Pharoah, M. (forthcoming) causation and information: where is biological meaning to be found? Biosemiotics.

Pigliucci, M., 2009. An extended synthesis for evolutionary biology. Ann. N. Y. Acad. Sci. $1168,218-228$.

Pigliucci, M., Müller, G. (Eds.), 2010. Evolution: the Extended Synthesis. MIT Press, Cambridge, MA.

Pinker, S., Bloom, P., 1990. Natural language and natural selection. Behav. Brain Sci. 13 (4), 707-727.

Queller, D.C., 1992. A general model for kin selection. Evolution 46, 376-380.

Richerson, P.J., Boyd, R., 2005. Not by Genes Alone: How Culture Transformed Human Evolution. University of Chicago Press, Chicago.

Ridley, M., 2010. The Rational Optimist: How Prosperity Evolves. Harper, New York.

Robinson, G.E., Fernald, R.D., Clayton, D.F., 2008. Genes and social behavior. Science 322 (5903), 896-900.

Saussure, F., 1983. Course in General Linguistics. Duckworth, London.
Schaik, C.P., Burkart, J.M., 2011. Social learning and evolution: the cultural intelligence hypothesis. Philos. Trans. R. Soc. Lond. B Biol. Sci. 366 (1567), 1008-1016.

Shapiro, J., 2011. Evolution: A view from the 21st century. FT Press, Upper Saddle River, NJ.

Stanley, S.M., 1975. A theory of evolution above the species level. Proc. Natl. Acad. Sci. Unit. States Am. 72, 646.

Steels, L., Szathmáry, E., 2018. The evolutionary dynamics of language. Biosystems 164, $128-137$.

Steffensen, S.V., Fill, A., 2014. Ecolinguistics: the state of the art and future horizons. Lang. Sci. 41, 6-25.

Sterelny, K., 2016. Cumulative cultural evolution and the origins of language. Biological Theory 11 (3), 173-186.

Stotz, K., 2010. Human nature and cognitive-developmental niche construction. Phenomenol. Cognitive Sci. 9 (4), 483-501.

Stotz, K., 2014. Extended evolutionary psychology: the importance of transgenerational developmental plasticity. Front. Psychol. 5, 908.

Stotz, K., 2017. Why developmental niche construction is not selective niche construction: and why it matters. Interface focus 7 (5), 20160157.

Stotz, K., Griffiths, P., 2016. A niche for the genome. Biol. Philos. 31 (1), 143-157.

Su, S., Cai, F., Si, A., Zhang, S., Tautz, J., Chen, S., 2008. East learns from west: asiatic honeybees can understand dance language of European honeybees. PloS One 3 (6), e2365.

Sukhoverkhov, A.V., 2010. Memory, sign systems, and self-reproductive processes. Biological Theory 5 (2), 161-166.

Sukhoverkhov, A.V., Fowler, C.A., 2014. Why language evolution needs memory: systems and ecological approaches. Biosemiotics 4 (1), 47-65, 8.

Sukhoverkhov, A.V., 2015. Non-genetic inheritance systems and new evolutionary synthesis. Tomsk State University Journal 397, 60-64.

Sutton, J., 2004. Representation, reduction, and interdisciplinarity in the sciences of memory, In: Clapin, H., Staines, P., Slezak, P. (Eds.), Representation in Mind. Elsevier, Amsterdam, pp. 187-216.

Sutton, J., 2008. Between individual and collective memory: coordination, interaction, 75. distribution//Social Research, pp. 23-48.

Svensson, E.I., 2018. On reciprocal causation in the evolutionary process. Evol. Biol. 45 (1), 1-14.

Thornton, A., Raihani, N.J., 2010. Identifying teaching in wild animals. Learn. Behav. 38 (3), 297-309.

Trivers, R.L., 1971. The evolution of reciprocal altruism. Q. Rev. Biol. 46, 35-57.

Trivers, R.L., 1985. Social Evolution. Benjamin/Cummings, Menlo Park, CA.

Uller, T., Helanterä, H., 2013. Non-genetic inheritance in evolutionary theory: a primer. Non-Genetic Inheritance 1, 27-32.

Uller, T., Helanterä, H., 2019. Niche construction and conceptual change in evolutionary biology. Br. J. Philos. Sci. 70 (2), 351-375.

Vrba, E., Gould, S.J., 1986. The hierarchical expansion of sorting and selection: sorting and selection cannot Be equated. Paleobiology 12, 217-228.

Vygotsky, L.S., 1981. The genesis of higher mental functions. In: Wertsch, J.V. (Ed.), The Concept of Activity in Soviet Psychology. Sharpe, Armonk, NY, pp. 144-188.

West, S.A., Cooper, G.A., 2016. Division of labour in microorganisms: an evolutionary perspective. Nat. Rev. Microbiol. 14 (11), 716-723.

White, S.A., 2001. Learning to communicate. Curr. Opin. Neurobiol. 11 (4), 510-520.

Whiten, A., Spiter, A., Horne, V., Bonnie, K., Lambeth, S., Schapiro, S., de Waal, F. 2007. Transmission of multiple traditions within and between chimpanzee groups. Curr. Biol. 17 (12), 1038-1043.

Wiggins, G.A., Tyack, P., Scharff, C., Rohrmeier, M., 2015. The evolutionary roots of creativity: mechanisms and motivations. Phil. Trans. Biol. Sci. 370 (1664), 20140099.

Wilson, D.S., 1980. The Natural Selection of Populations and Communities. Benjamin/ Cummings, Menlo Park, CA.

Wilson, D.S., Sober, E., 1989. Reviving the superorganism. J. Theor. Biol. 136 (3), 337-356.

Wilson, D., Sober, E., 1994. Reintroducing group selection to the human behavioral sciences. Behav. Brain Sci. 17 (4), 585-608.

Woolfson, A., 2016. The human superorganism: how the microbiome is revolutionizing the pursuit of a healthy life. Nature 536 (7615), 146-147. 